ACTA MYCOLOGICA

Vol. 41 (2): 285-298

2006
Dedicated to Professor Alina Skirgietto

on the occasion of her ninety fifth birthday

\title{
The genus Fusicladium (Hyphomycetes) in Poland
}

\author{
MAŁGORZATA RUSZKIEWICZ MICHALSKA and EWA POŁEĆ \\ ${ }^{1}$ Department of Algology and Mycology, University of Łódź, Banacha 12/16, PL 90237 Łódź \\ mrusz@biol.uni.lodz.pl; ewa_polec@op.pl
}

Ruszkiewicz Michalska M., Połeć E.: The genus Fusicladium (Hyphomycetes) in Poland. Acta Mycol. 41 (2): 285 298, 2006.

The paper presents new and historical data on the genus Fusicladium verified on the base of the recently published critical monograph. Fifteen species recorded in Poland under the name Fusicladium and synonymous Pollaccia and Spilocaea are reported; 5 are documented by authors' materials from Central Poland while the other taxa are supported with literature data only, including three species belonging currently to Fusicladiella and Passalora. Three species, reported here for the first time in Poland: Fusicladium convolvularum Ondřej, F. scribnerianum (Cavara) M. B. Ellis and $F$. virgaureae Ondřej, are known from a few localities in the world. All the species are provided with the distribution maps and the newly reported ones are illustrated with ink drawings.

Key words: parasitic fungi, anamorphic fungi, Deuteromycotina, distribution, Poland

\section{INTRODUCTION}

Worldwide 57 fungal taxa belong to the anamorphic genus Fusicladium Bonord. em. Schubert, Ritschel et U. Braun. They are phytopathologically relevant pathogens, causing leaf spots, necroses, scab diseases as well as leaf and fruit deformations of members of at least 52 angiospermous plant genera (Schubert, Ritschel, Braun 2003). The fungi are host specific, mostly confined to a single host genus or allied host genera in a single family, e.g. Fusicladium pomi parasitizing the members of Rosaceae. The teleomorphic stages belonging to Venturiaceae (Ascomycota) develop after the mycelium overwinters in plant organs.

The name Fusicladium was traditionally used for Venturia anamorphs having sympodial (denticulate) or percurrent (annellate) conidiogenous cells. Three genera were later distinguished depending on the proliferation mode: Fusicladium with sympodial proliferation, Pollaccia with monoblastic, determinate to percurrent conidiogenous cells (with few rather inconspicuous annellations) and Spilocaea with percurrent proliferation and numerous, conspicuous annellations 
(Schubert et al. 2003). The division has been accepted in many literature reports (e.g. Ellis 1976; Brandenburger 1985; Revay 1998).

Due to the number of taxa with mixed types of conidiogenous cells, these features are insufficient for the generic separation and it was not maintained by the authors of the first monograph of Fusicladium (Schub e rt et al. 2003). They reduced names Pollaccia E. Bald. et Cif. and Spilocaea Fr. to synonymy with Fusicladium Bonord., postulating to preserve the name instead of the older Spilocaea. The decision to merge these genera is supported by light and electron microscopy research and molecular data which show that features such as the type and growth of the mycelium, arrangement of conidiophores, structure of conidiogenous loci and shape, size and formation of conidia may not be used to define various genera of anamorphs belonging to Venturiaceae. These features are, however, useful for distinguishing species.

Properties that enable the differentiation of Fusicladium from other hyphomycetous genera are as follows: mycelium and stromata usually subcuticular to intraepidermal, hyphae often radiating, forming hyphal plates, conidiophores usually erumpent through the cuticle, pigmented and with equally thickened wall, conidiogenous loci inconspicuous with always unthickened wall, conidia pigmented, mostly olivaceous, solitary or catenate, amero- to phragmosporous, 0-2(-4)-septate.

\section{MATERIALS AND METHODS}

Available literature data were critically analysed and used to prepare a list of Fusicladium species recorded in Poland and maps of their distribution. Phytopathological reports of economically important species were omitted for the sake of clarity and mainly 'floristic' data were used below.

The original material consisting of plant organs affected by Fusicladium species was collected in Central Poland: in the region of Łódź city and in the Wyżyna Częstochowska Upland.

For microscopic examination, specimens were made in lactic acid and heated with an alcohol burner. Nikon SMZ $10 \mathrm{~A}$ and Nikon E 400 microscopes were used to identify fungal species which were determined according to Schub e r t et al. (2003). Features of these specimens correspond to those given there. The nomenclature of host plants is given after Mirek et al. (2002).

The study material is deposited in the Herbarium Universitatis Lodziensis (LOD) in the collection of parasitic fungi labelled as PF.

\section{RESULTS}

According to Schubert et al. (2003) 7 taxa are known to occur in Poland, namely Fusicladium betulae, F. radiosum var. populi-albae, F. radiosum var. radiosum, F. saliciperdum, Fusicladium sp. and common in Europe - F. pomi and F. pyrorum. A thorough review of the Polish mycological literature has revealed that 6 other species have also been recorded in Poland under the names Fusicladium, Pollaccia and Spilocaea. Three of these species are currently classified in different genera: 2 belong to Passalora and 1 is synonymized with Fusicladiella melaena. The list of species occurring in Poland is supplemented with 3 species new to the country: Fusicladium convolvularum, F. scribnerianum and $F$. virgaureae. 


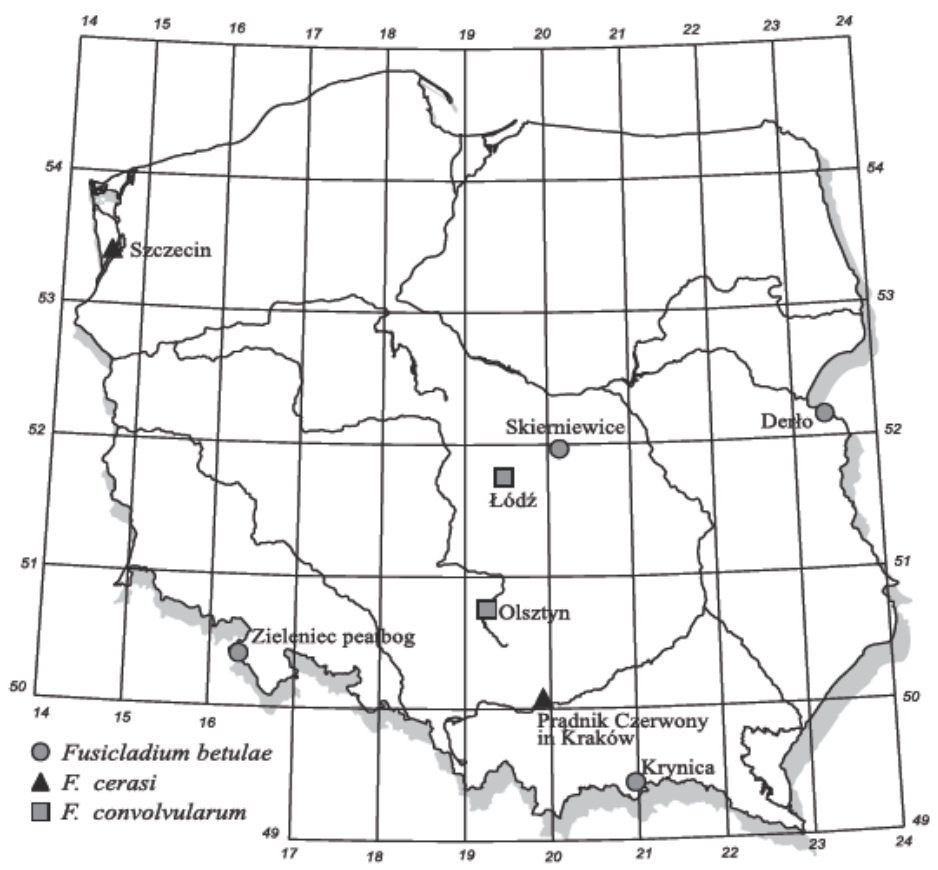

Fig. 1. Distribution of Fusicladium species.

Fusicladium betulae Aderh., Centralb. Bakteriol., 2 Abth., 2: 57 (1896) and Hedwigia 36: 80 (1897), teleomorph: Venturia ditricha (Fr.) P. Karst.

Distribution. On Betula nana: Zieleniec peat bog (Starmachowa 1964); on Betula pendula: Nieborów forest near Skierniewice (Zweigbaumówna 1925), Góra Krzyżowa Mt. near Krynica (St a r m a ch ow a 1966), Derło in Bug river valley (Da nilkiewicz 1987) (Fig. 1). According to Schubert et al. (2003) this fungus is known from Poland on $B$. pendula.

Notes. Two Fusicladium species are known on the members of Betulaceae: F betulae and $F$. scribnerianum, which is characterized by darkened-refractive hila and loci (Schubert et al. 2003). F. betulae is common on B. pendula, but on B. nana is known from Denmark, Norway and Romania (Farr et al. 2006).

Fusicladium cerasi (Rabenh.) Erikss., Meddeland. Kongl. Lantbruksakad. Exp.fält 1: 73 (1885), teleomorph: Venturia cerasi Aderh.

Distribution. On Cerasus avium [ Prunus avium]: Szczecin (Madej 1974); on C. vulgaris [ Prunuscerasus]: Prądnik Czerwony in Kraków (Namysłowski 1914) and Szczecin (Madej 1974) (Fig. 1).

Notes. The Prunus species (including Cerasus) could be infected with 5 species of Fusicladium. Cerasus vulgaris is worldwide affected mostly by $F$. cerasi, but also 2 other species have been reported so far: Fusicladium-state of Apiosporina morbosa (Schwein.) Arx and F carpophilum occurring very rarely on this host (Schubert et al. 2003). The distribution of F cerasi on $C$. vulgaris is circumglobal: it is known from Asia, North and South Americas, Australia, New Zealand and numerous European countries. 


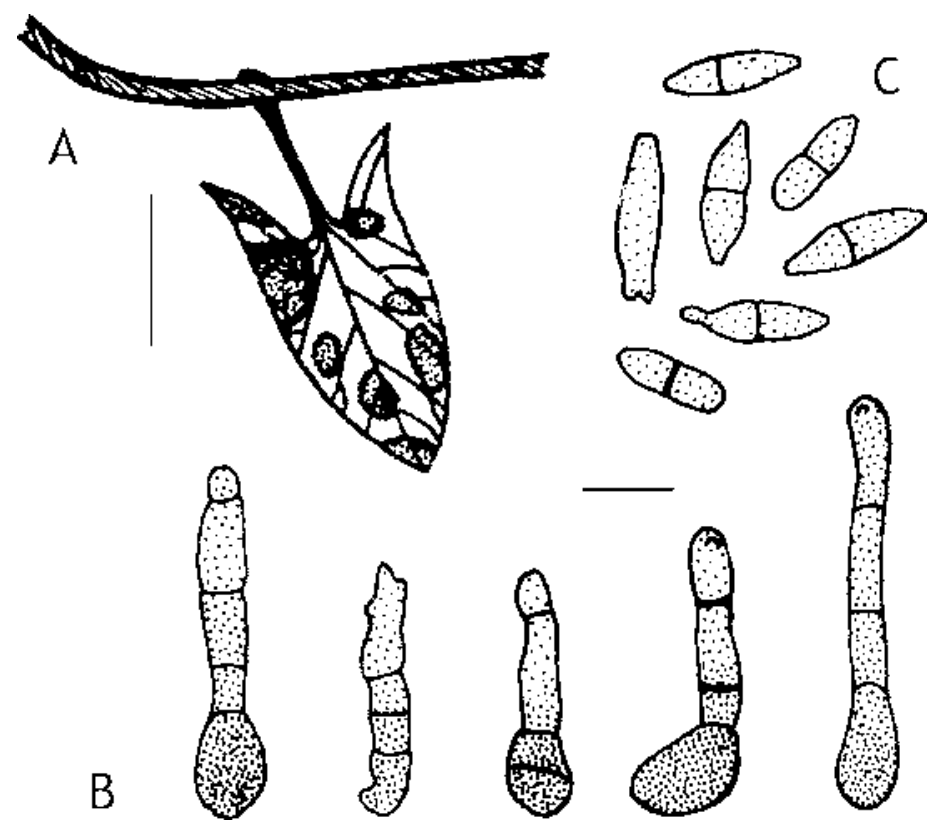

Fig. 2. Fusicladium convolvularum on Convolvulus arvensis: A leaf with spots, B conidio phores, C conidia; scale bars A $10 \mathrm{~mm}, \mathrm{~B} \quad \mathrm{C} \quad 10 \mu \mathrm{m}$.

Fusicladium convolvularum Ondřej, Česká Mycol. 25 (3): 171 (1971), teleomorph unknown.

Leaf spots amphigenous, 1-3 mm wide, brown, later with greyish brown centre and brown margin. Conidiophores solitary or in small groups, arising from stromatic cells, straight, or curved at the apex, subcylindrical to geniculate-sinuous, 29.4-44.1 $\mathrm{x}$ 4.2-4.9 $\mu \mathrm{m}, 0-1(-3)$-septate, pale to medium brown, smooth. Conidiogenous cells terminal with a single or several conidiogenous loci, proliferation sympodial, loci unthickened, not or often somewhat darkened-refractive. Conidia solitary or occasionally in unbranched or branched chains, ellipsoid-ovoid, fusiform, subcylindrical, 17.1-22.3 x 4.9-5.2 $\mu \mathrm{m}, 0-1$-septate, mostly constricted at the septa, pale olivaceous, smooth, hila 1.9-2.5 $\mu \mathrm{m}$ wide, flat, not or somewhat darkened-refractive (Fig. 2).

Specimens eXamined. On Convolvulus arvensis: Central Poland, Wyżyna Częstochowska Upland, at NE base of the Góra Lipówki Bliskie hill near Olsztyn, roadside, 21 Aug. 1998, leg. M. Ruszkiewicz-Michalska, LOD 885; Łódź, Botanical Garden, Sect. of medicinally and industrially important plants, weed overgrowing Convallaria majalis, 21 Aug. 2004, leg. E. Połeć, LOD 2261; Łódź, "Sielanka" park, near Pabianicka Str., weed overgrowing Kerria japonica, 27 June 2005, leg. M. Ruszkiewicz-Michalska et M. Jakiel, LOD 2229 (Fig. 1).

Notes. The fungus parasitizes members of the genera Calystegia and Convolvulus. It has been reported on Calystegia soldanella from Great Britain, on Calystegia sepium and Convolvulus arvensis from the Czech Republic, and on the latter host also from New Zealand (Farr et al. 2006). The species has been observed in Poland for the first time. 


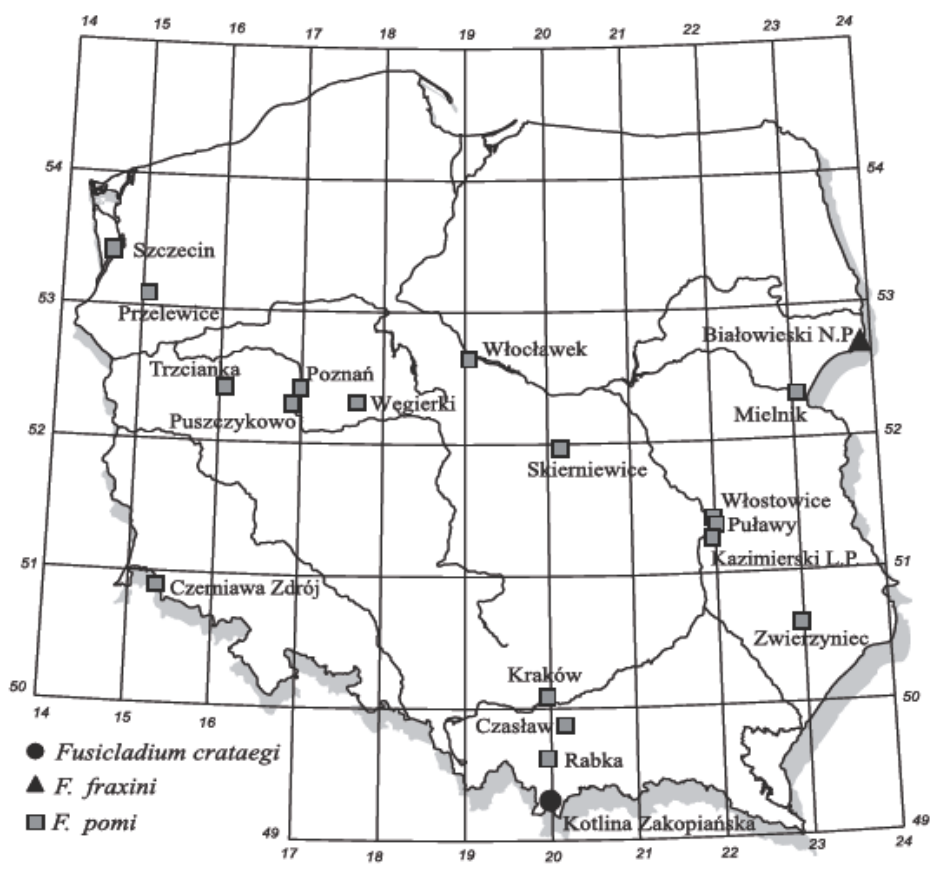

Fig. 3. Distribution of Fusicladium species.

Fusicladium crataegi Aderh., Ber. Deutsch. Bot. Ges. 20: 200 (1902), teleomorph: Venturia crataegi Aderh.

Distribution. On Crataegus coccinea L.: Kotlina Zakopiańska basin in the Tatra Mts. (Sa ła ta et al. 1993) (Fig. 3).

NoTES. According to Sch ube rt et al. (2003) only this cosmopolitan fungus parasitizes the members of Crataegus. As $C$. coccinea or its synonyms have not been listed among the species infected with F. crataegi (S chuber t et al. 2003; Farr et al. 2006) it is presumably a new host of the fungus.

Fusicladium fraxini Aderh., Hedwigia 36: 74, 83 (1897), 三 Spilocaea fraxini (Aderh.) Sivan., teleomorph: Venturia fraxini Aderh.

Distribution. On Fraxinus excelsior: as $S$. fraxini, Białowieski National Park, Tilio-Carpinetum, Circaeo-Alnetum, Carici elongatae-Alnetum plant associations (Mułenko 1994, provided with a description and ink drawing; Faliński, Mułenko 1997) (Fig. 3).

NoTEs. Mixed, percurrent and sympodial proliferations of conidiogenuous cells may occur in this species within a single collection and therefore the taxon is considered intermediate between Fusicladium s. str. and Spilocaea. Worldwide, members of the genus Fraxinus are parasitized by 2 species of Fusicladium: $F$ fraxini and $F$. nebulosum; the latter is known only from the type material collected in North America. These 2 species differ by the arrangement, shape and size of conidiophores as well as by the type of the conidial sculpture (S chu bert et al. 2003). 
Fusicladium pomi (Fr.) Lind, Dan. fung.: 521 (1913), $\equiv$ F. dendriticum (Wallr.) Fuckel, F. orbiculatum (Desm.) Thüm., Spilocaea pomi Fr.: Fr., teleomorph: Venturia inaequalis (Cooke) G. Winter.

Distribution. As F. dendriticum: on Malus pumila, Szczecin (Zaleski, Madej 1964); on Malus sylvestris, Czasław, Rabka, Prądnik Czerwony and Czarna Wieś in Kraków (Namysłowski 1914), Puławy, Włostowice (Ko nopacka 1924), Skierniewice (Zweigbaumówna 1925), Botanical Garden in Kraków (Wróblewski 1925), near Czerniawa Zdrój (Laubert 1931), Poznań, Puszczykowo, Węgierki, Włocławek (D o minik 1936); on Pyrus baccata, Trzcianka (D o minik 1935, 1936); as F. orbiculatum: on Sorbus aucuparia, Zwierzyniec (Zw e ig b a u mów n a 1925); on Sorbus latifolia (D om in ik 1963); as S. pomi: on Malus domestica, M. pumila, M. × purpurea and Malus sp.: Przelewice, Szczecin (Madej 1971, 1974); on Malus spp.: Kazimierski Landscape Park (Ro m aszew ska-Sała ta et al. 1991-1992); on Malus sylvestris: Mielnik (Romaszewska-Sała ta, Mułenko 1983) (Fig. 3).

Notes. This cosmopolitan, polyphagous and economically important species has so far been noted on 12 host genera of the Rosaceae family, but it mainly infects representatives of Malus: M. domestica, M. prunifolia and M. sylvestris (Trieb el 1999; Schubert et al. 2003).

Fusicladium pyrorum (Lib.) Fuckel, Jahrb. Nassauischen Vereins Naturk. 23-24: 357 '1869' (1870), as "F. pyrinum”, teleomorph: Venturia pyrina Aderh.

Specimen examined. On Pyrus communis, Central Poland, Łódź, "Sielanka” park, near Pabianicka Str., ornamental, 27 June 2005, leg. M. Ruszkiewicz-Michalska et M. Jakiel, LOD 2206.

Distribution. As F. pirinum: on Pyrus communis, without precised locality (Chełchowski 1902), Czarna Wieś and Prądnik Czerwony in Kraków (Namysłowski 1914), Puławy, Kazimierz (Konopacka 1924), Skierniewice (Zweigbaumówna 1925), near Czerniawa Zdrój (Laubert 1931), Włocławek (Dominik 1935, 1936), Szczecin (Zaleski, Madej 1964), Leba, Cetniewo (Michalski 1967), Neple, Gnojno in the Bug river valley (Danilkiewicz 1987); as F. pyrorum: on Pyrus domestica, Przelewice and Szczecin (Madej 1974) (Fig. 4).

Notes. The fungus infects mainly Pyrus communis, but it may also be found on the members of 4 other genera belonging to the Pomoideae, including Malus species, which are above all parasitized by F. pomi (Schubert et al. 2003). The latter differs from F. pyrorum by the proliferation type of conidiogenous cells (percurrent vs. sympodial) and width of loci (4-5 $\mu \mathrm{m}$ vs. 1-3 $\mu \mathrm{m})$.

Fusicladium radiosum (Lib.) Lind var. populi-albae (M. Morelet) Ritschel et U. Braun, Ann. Mycol. 3: 340 (1905), 三 Pollaccia radiosa (Lib.) E. Bald. et Cif., teleomorph: Venturia tremulae Aderh.

Specimen examined. On Populus alba: Central Poland, Chechło II near Łódź, near the railroad, 13 Sept. 2000, leg. M. Ruszkiewicz, LOD 2501. The dimensions of conidia (1-septate, 8.6-9.1 $\mu \mathrm{m}$ wide) correspond to the range given for this variety in the Fusicladium monograph (Schubert et al. 2003).

Distribution. For the list of Polish localities of the fungus on Populus alba, $P$. nigra and P. tremula see Mułen ko (1996) (Fig. 4). According to the data of Schubert et al. (2003) two varieties of this species are known from Poland: var. radiosum (on P. tremula) and var. populi-albae (on P. alba). 


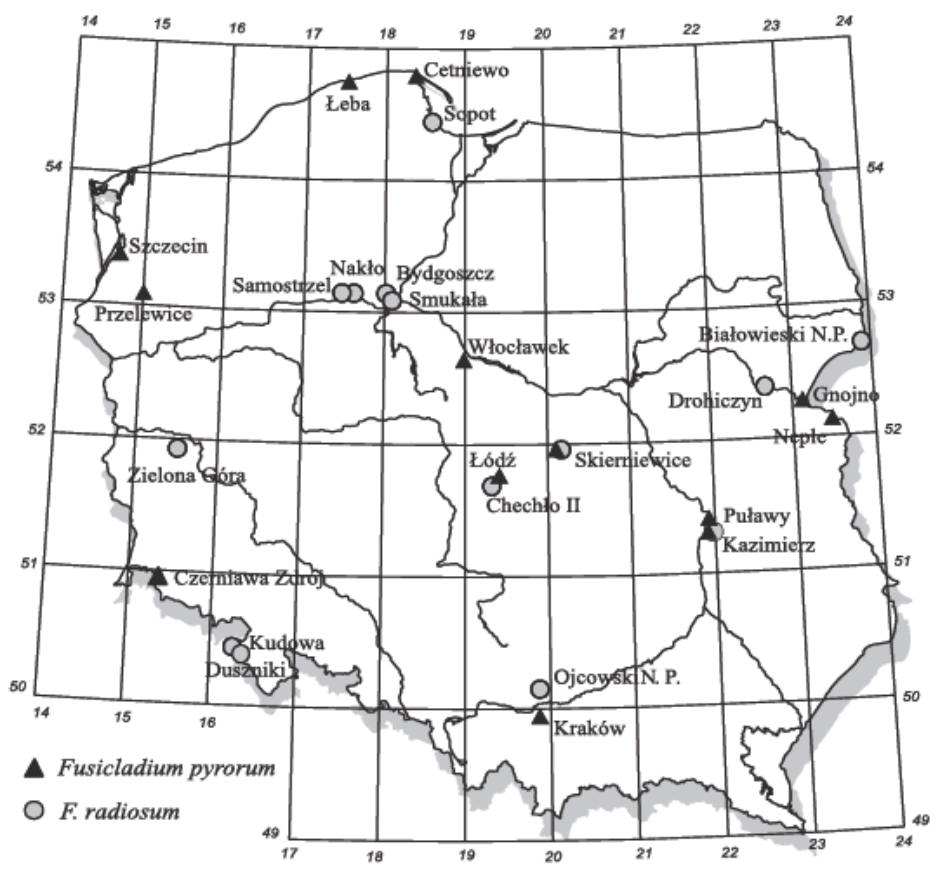

Fig. 4. Distribution of Fusicladium species.

Notes. The members of the genus Populus could be infected with 8 taxa belonging to 6 Fusicladium species. The diversification of one of them, Fusicladium radiosum, into varieties is based on the septation, width and shape of conidia (Schu bert et al. 2003). As the records in the Polish literature are not provided with morphological descriptions of the fungus, they may not be assigned to any of the varieties of $F$ radiosum. Morphological and morphometric analyses of the $F$. radiosum complex (Schubert et al. l.c.) have shown, however, that differences in the conidial size observed among varieties are not distinct. A strict host-based separation is not evident either as Populus alba is infected by all varieties of this species. The molecular approach is needed to re-assess this complex.

Fusicladium saliciperdum (Allesch. et Tubeuf) Tubeuf, Arbeiten Biol. Reichsanst. Land-Forstw. 2: 568 (1902), 三 Fusicladium saliciperdum (Allesch. et Tubeuf) Lind, teleomorph: Venturia saliciperda J. Nüesch.

Distribution. On Salix babylonica: near Duszniki (La uber t 1931) (Fig. 5). According to Schubert et al. (2003) this species occurs on Salix americana in Poland. We have found no literature data confirming this record.

Notes. F saliciperdum is one of the 4 species of Fusicladium known to parasitize the members of the genus Salix. The host range of this fungus is the broadest: worldwide it infects 28 host taxa, including hybrids (Schubert et al. l.c.). It has been recorded on S. babylonica in Canada, China, Germany, Great Britain, Russia and the United States of America (Farr et al. 2006). 


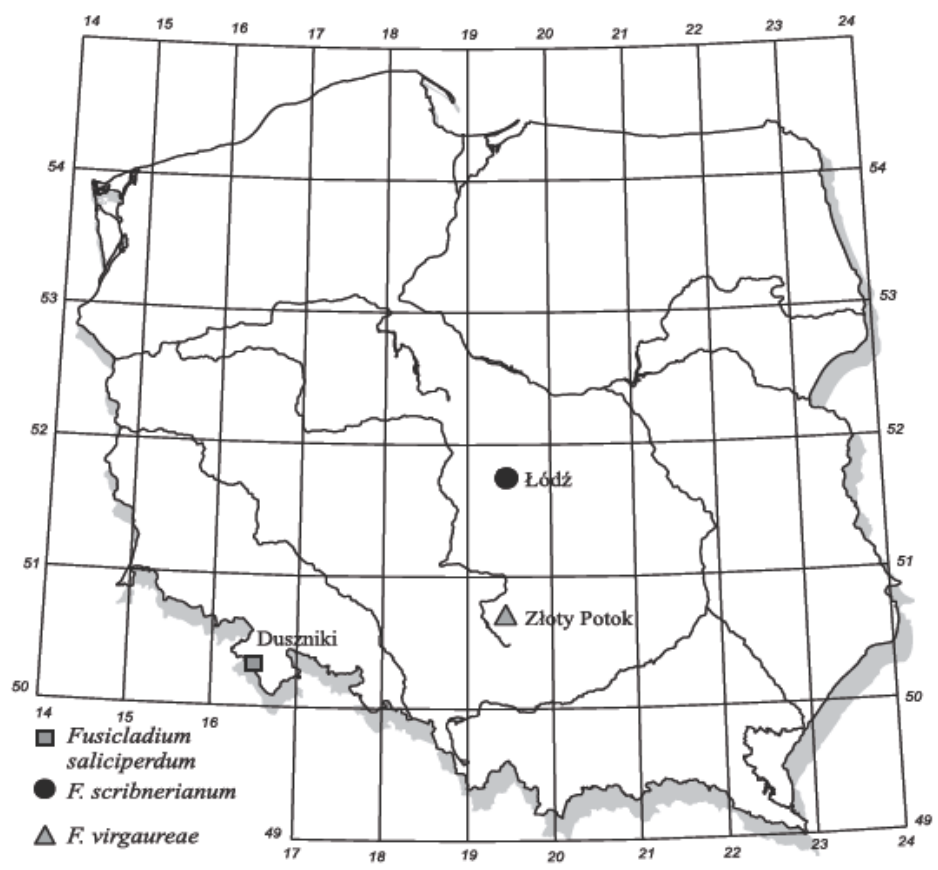

Fig. 5. Distribution of Fusicladium species.

Fusicladium scribnerianum (Cavara) M. B. Ellis, More Dematiaceous Hyphomycetes: 238 (1976), teleomorph unknown.

Leaf spots amphigenous, subcircular, on the upper leaf surface olivaceous-greyish to dark brown, centre of the spot darker. Stromata composed of brown, thickwalled cells. Conidiophores solitary or loosely to densely fasciculate, arising from stromata, erect, straight to slightly flexuous, unbranched, 19.8-41.7 x 4.2-4.9 $\mu \mathrm{m}$, 0-1-septate, olivaceous to pale brown, smooth. Conidiogenous cells terminal with a single or several conidiogenous loci, proliferation sympodial, loci unthickened, but somewhat darkened-refractive. Conidia solitary or sometimes catenate, fusiform to cylindrical, straight, 14.7-27.0 x 4.7-6.1 $\mu \mathrm{m}, 0-3$ septate, pale olivaceous, smooth, hila unthickened, but somewhat darkened-refractive (Fig. 6).

Specimen examined. On Betula pendula: Central Poland, Łódź, Botanical Garden, Sect. of Arboretum, 20 July 2004, leg. E. Połeć, LOD 2262 (Fig. 5). Morphological features of the specimen correspond to those described by Sch ube rt et al. (2003).

Notes. The species is known on $B$. pendula, B. populifolia and Betula sp. from Australia, Germany, Italy, Kazakhstan (Dugan et al. 2004; Farr et al. 2006). The species is reported from Poland for the first time.

Fusicladium sp., anamorph of Venturia chlorospora (Ces.) P. Karst.

Distribution. According to Schubert et al. (2003) the species occurs on Salix fragilis in Poland. We did not find any record in the available literature to confirm this information.

Notes. The species is known in the anamorphic stage only from in vitro cultures formed by Venturia chlorospora ascospores. It is characterised by: conidiophores 

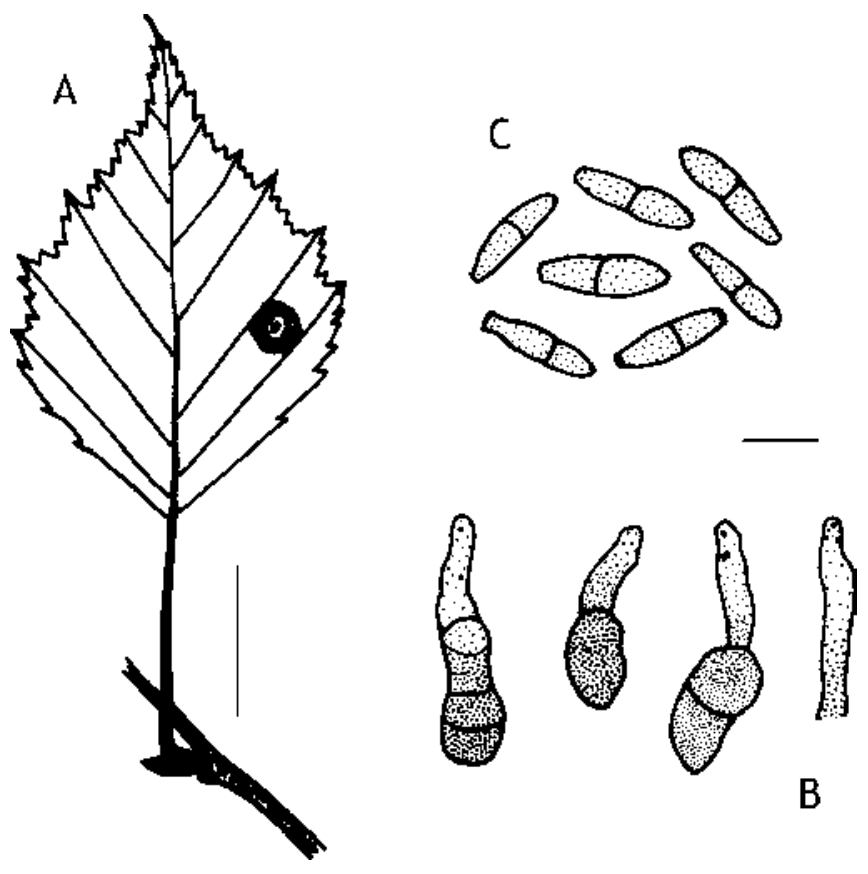

B

Fig. 6. Fusicladium scribnerianum on Betula pendula: A leaf with spot, B conidiophores, C conidia; scale bars: A $10 \mathrm{~mm}$, B C $10 \mu \mathrm{m}$.

arising as lateral branches of brown hyphae, conidiogenous cells polyblastic, sympodial, terminal or intercalary, with numerous conidiogenous loci and conidia in unbranched chains, 5-8 $\mu \mathrm{m}$ wide ( $\mathrm{Sch}$ u bert et al. 2003). V. chlorospora is known on 7 Salix species from Poland (Farr et al. 2006).

Fusicladium virgaureae Ondřej, Česká Mycol. 25 (3): 170 (1971), teleomorph unknown.

Leaf spots amphigenous, shape and size variable, irregular, yellowish, olivaceous to brown. Conidiophores solitary or in small, loose fascicles, erect, straight to somewhat flexuous, subcylindrical to slightly sinuous, unbranched or rarely branched, 36.8-63.7 x 4.9-5.4 $\mu \mathrm{m}$, septate, yellowish or olivaceous-brown to medium brown, smooth. Conidiogenous cells terminal with a single or up to four loci, proliferation sympodial. Conidia in unbranched chains, cylindrical to fusiform or obclavate, straight, 13.5-15.9 x 4.4-5.2 $\mu \mathrm{m}, 0$-1-septate, yellowish or olivaceous-brown, smooth, hila neither thickened nor darkened (Fig. 7).

Specimen eXamined. On Solidago serotina: Central Poland, Wyżyna Częstochowska Upland, Złoty Potok near Częstochowa, manor park, roadside, 25 Aug. 1998, leg. M. Ruszkiewicz, LOD 886 (Fig. 5).

NotEs. F. virgaureae is the only species of this genus parasitizing plants belonging to the Asteraceae. It infects only the members of the genus Solidago and is known from 3 countries. Occurrence of the fungus has been reported on S. gigantea from Austria and on $S$. virgaurea from the Czech Republic and Slovakia (Schubert et al. 2003; Farr et al. 2006). The species is new to the Polish mycobiota. 

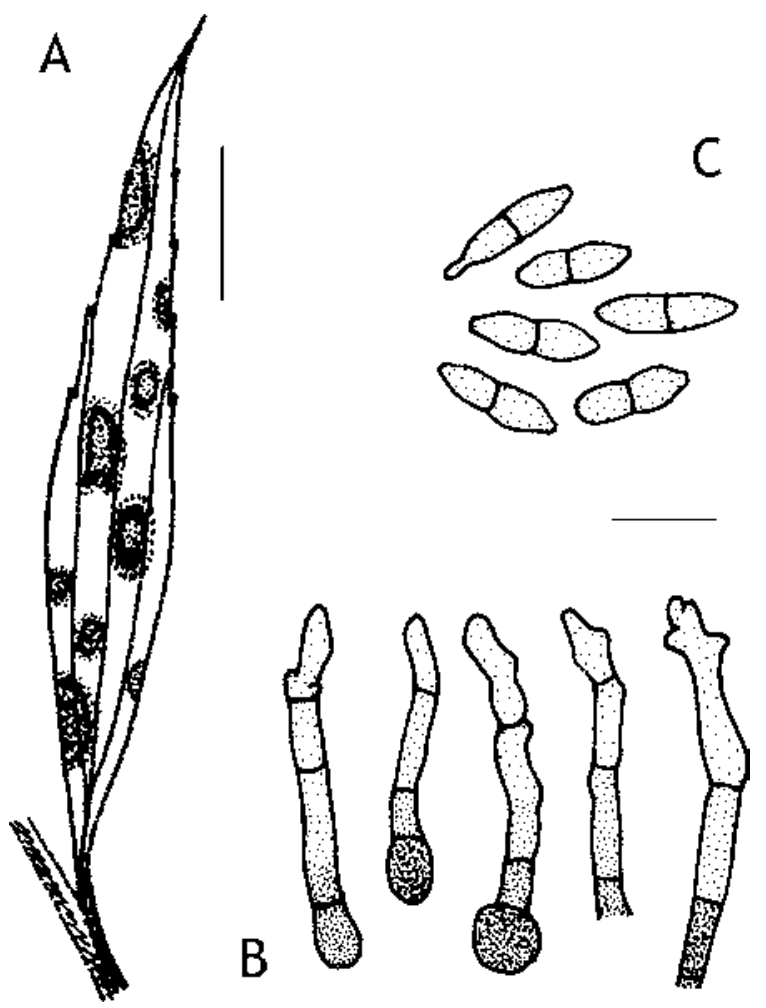

Fig. 7. Fusicladium virgaureae on Solidago serotina: A leaf with spots, B conidiophores, C conidia; scale bars A $10 \mathrm{~mm}$, B C $10 \mu \mathrm{m}$.

\section{EXCLUDED SPECIES}

Fusicladium aronici Sacc., Michelia 2: 171 (1880).

Distribution. On Doronicum austriacum and D. clusii: numerous localities in the Tatra Mts. (Starmachowa 1963; Mułenko et al. 2004).

Noтеs. This species currently belongs to Fusicladiella melaena (Fuckel) S. Hughes (Schubert et al. 1. c.). The genus Fusicladiella differs from Fusicladium by forming membranaceous mycelium and stromata, having older conidiophores usually curved and conidiogenous loci thickened and darkened.

Fusicladium depressum (Berk. et Broome) Roum., Fungi gall. exs. 86 (1879).

Distribution. For the list of host species and Polish localities see Mułenko (1996).

Notes. According to Schubert et al. (2003) and Crous \& Braun (2003) this name is now synonymized with Passalora depressa (Berk. et Broome) Sacc.

Fusicladium heterosporum Höhn., Ann. Mycol. 3: 337 (1905).

Distribution. On Chamaenerion angustifolium: Włoszczowa (Mo esz 1926).

Notes. The species is currently considered to be Passalora heterospora (Höhn.) Höhn. (Schubert et al. l.c.; Crous, Braun 1.c.). 


\section{FINAL REMARKS}

The first Polish records of taxa currently belonging to Fusicladium are dated back to the beginning of 20th century (Chełch ow ski 1902). The most of the older findings come from floristic or phytopathological investigations (Na mysłows ki 1914; Laubert 1921, 1931; Konopacka 1924; Wróblewski 1925; Zweigbaumówna 1925; Dominik 1936, 1963; Starmachowa 1964, 1966; Zaleski, Madej 1964; Michalski 1967; Madej 1971, 1974). The more recent data are provided by mycocoenological studies carried out in a few Polish regions of a special floristic value: Białowieża National Park (Mułenko 1994, 1996), Tatra Mts. (S ała ta et al. 1993) and Wyżyna Lubelska Upland (Romaszewska-Sałata, Mułenko 1983; Danilkiewicz 1987; Romaszewska-Sałata et al. 1991-1992).

The best documented is occurrence of common, economically important species - Fusicladium pomi and F. pyrorum (compare Figs 3, 4). The other species are known from a few localities in Poland, mainly from more intensively investigated areas. Many other regions of the country, are still less studied and therefore the listed localities of these species do not present their comprehensive distribution.

The 3 newly recorded taxa are known from a few countries only, on different continents, e.g. Fusicladium scribnerianum has been reported from Europe, Asia and Australia. This distribution implies that actually they are not very rare or restricted to certain areas. The assumption is supported with our findings, especially that of Fusicladium convolvularum, which has been repeatedly collected in Central Poland since its discovery on the Wyżyna Częstochowska Upland in 1998.

Acknowledgement: Authors are grateful to Dr. Uwe Braun (Halle/Saale, Germany) for providing the es sential literature. The studies were partially supported by the University of Łódź (grant no 505/396 and no 505/397).

\section{REFERENCES}

Brandenburger W. 1985. Parasitische Pilze an Gefäßpflanzen in Europa. G. Fischer Verlag, Stutt gart New York, 1248 pp.

Chełchowski S. 1902. Spostrzeżenia grzyboznawcze (Observationes mycologicae polonicae). Pam. Fizjogr. 17: 138.

Crous P. W., Brau U. 2003. Mycosphaerella and its anamorphs: 1. Names published in Cercospora and Passalora. CBS Biodiversity Series 1: 1571.

D a nilki ew i cz M. 1987. Grzyby pasożytnicze lewobrzeżnej doliny środkowego Bugu (Parasitic fungi of river Bug valley). Acta Mycol. 23 (2): 3780.

Dominik T. 1935. Grzyby pasożytnicze zebrane w okolicy Włocławka w sierpniu 1934 roku. Acta Soc. Bot. Pol. 12 (2): 201205.

Dom in ik T. 1936. Materiały do flory grzybów mikroskopowych zachodniej Polski (Beiträge zur Kennt nis der mikroskopischen Pilzflora Westpolens). Spraw. Kom. Fizjogr. 70: 172.

Dom in ik T. 1963. Notatki mikologiczne z lat 1945 1960. Zesz. Nauk WSR Szczecin 10: 4777.

Dugan F. M., Schubert K., Braun U. 2004. Check list of Cladosporium names. Schlechtendalia 11: 1103.

E1lis M. B. 1976. More Dematiaceous Hyphomycetes. CAB International Mycological Institute, Kew, Surrey, $507 \mathrm{pp}$.

Faliński J. B., Mułenko W. (eds). 1997. Cryptogamous plants in the forest communities of Białowieża National Park. Ecological atlas (Project CRYPTO 4). Phytocoenosis 9 (N. S.), Suppl. Cartogr. Geo bot. 7: 1522 . 
Farr D.F., Rossman A.Y., Palm M.E., McCray E.B. 2006. Fungal Databases, Systematic Botany \& Mycology Laboratory, ARS, USDA. Retrieved April 2, 2006, from http://nt.ars grin.gov/fungal databases/.

Kon op a ka W. 1924. Grzyby pasożytnicze okolic Puław i Kazimierza (Les champignons parasites des environs de Puławy et de Kazimierz). Kosmos 49: 855872.

La ub ert R. 1931. Schmarotzerpilze aus den Sudeten. Zeitschr. f. Pilzk. 15 (A.F.): 4249.

Madej T. 1971. Mikoflora drzew i krzewów ogrodu dendrologicznego w Przelewicach (woj. Szczecin) (Mycoflora of trees and shrubs of the dendrologic garden at Przelewice (Province of Szczecin). Fragm. Flor. Geobot. 17: 583600.

Madej T. 1974. Materiały do mikoflory roślin woj. szczecińskiego. Akademia Rolnicza w Szczecinie, Rozprawy 35: 1235.

Michalski A. 1967. Grzyby pasożytnicze Wybrzeża Gdańskiego (Les champignons phytopathogènes de la côte de la Baltique du district de Gdańsk (Pologne). Acta Mycol. 3: 153162.

Mirek Z., Piękoś Mirkowa H., Zając A., Zając M. 2002. Flowering plants and Pteridophytes of Poland. A checklist. (In:) Z. Mirek (ed.). Biodiversity of Poland 1. W. Szafer Institute of Botany, Polish Academy of Sciences, Kraków.

Moesz G. 1926. Additamenta ad cognitionem fungorum Poloniae. II. Continuatio secunda. Magyar Bot. Lapok. 25: 2539.

Mułenko W. 1994. Parasitic Hyphomycetes of the Białowieża National Park. I. Acta Mycol. 29 (1): 121 127.

Mułenko W. 1996. Parasitic Hyphomycetes of the Białowieża National Park. III. Acta Mycol. 31 (1): 311.

Mułenko W., Kozłowska M., Sałata B. 2004. Microfungi of the Tatra National Park. A checklist. Biodiversity of the Tatra National Park 1: 172.

Na mysłows ki B. 1914. Śluzowce i grzyby Galicji i Bukowiny (Myxomycetes et champignons de la Ga licie et Boukovinae). Pam. Fizjogr. 22: 1151.

Revay A. 1998. Review of the Hyphomycetes of Hungary. Studia bot. hung. 27 28: 574.

Romaszewska Sałata J., Mułenko W. 1983. Mikroskopijne grzyby fitopatogeniczne okolic Drohi czyna i Mielnika nad Bugiem (Microscopic phytopathogenic fungi of the environs of Drohiczyn and Mielnik upon Bug). Ann. UMCS, sect. C, 38: 1936.

Romaszewska Sałata J., Sałata B., Mułenko W. 1991 1992. Wstępne uwagi o mikroskopowych grzybach fitopatogenicznych Kazimierskiego Parku Krajobrazowego (Einleitungsbemerkungen über die mikroskopischen phytopathogenen Pilze des Kazimierer Landschaftspark). Folia Soc. Scie. Lub. 32 (1 2): 3139.

Sałata B., Romaszewska Sałata J., Mułenko W. 1993. Mikroskopowe grzyby fitopatogeniczne (Microscopic phytopathogenic fungi). (In:) Z. Mir ek, H. Pię koś Mirkowa (eds). Przyroda Ko tliny Zakopiańskiej poznanie, przemiany, zagrożenia i ochrona. Tatry i Podtatrze 2: 183207.

Schubert K., Ritschel A., Braun U. 2003. A monograph of Fusicladium s.lat. (Hyphomycetes). Schlechtendalia 9: 1132.

St a r m a ch ow a B. 1963. Grzyby pasożytnicze z Tatr (Les champignons parasitaires des Tatras). Monogr. Bot. 15: 153294.

S t a r m a ch ow a B. 1964. Grzyby pasożytnicze zebrane w Polanicy Zdroju, Dusznikach i innych miejsco wościach Ziemi Kłodzkiej (Dolny Śląsk). Fragm. Flor. Geobot. 10 (1): 8996.

St a r m a chowa B. 1966. Grzyby pasożytnicze Krynicy i okolicznych gór (Beskid Sądecki) (Les cham pignons parasitaires récoltés à Krynica et les montagnes qui l'entourent (Carpates Occidentales Polonaises). Fragm. Flor. Geobot. 12 (4): 471495.

Triebel D. 1999. Microfungi exsiccati. Fasc. 1518 (no 351 450). Arnoldia 17: 147.

Wróblews ki A. 1925. Spis grzybów zebranych przez Marjana Raciborskiego w okolicy Krakowa i w Ta trach w latach 1889 i 1890 (Champignons recueillis par M. Raciborski dans les environs de Cracovie et dans le Tatra en 1889 et 1890). Acta Soc. Bot. Pol. 3: 2941.

Zaleski K., Madej T. 1964. Choroby grzybowe drzew i krzewów owocowych, warzyw i roślin ozdob nych w ogrodach działkowych miasta Szczecina w roku 1958 (Fungus diseases of fruit trees and bu shes, vegetables and ornamental plants in allotment gardnes in the city of Szczecin in 1958). Roczn. WSR, Poznań 19: 209232.

Zweigba u mówn a Z. 1925. Grzyby okolic Skierniewic (Les champignons des environs de Skierniewi ce). Acta Soc. Bot. Pol. 2: 275301. 


\section{Przegląd krajowych gatunków z rodzaju Fusicladium}

\section{Streszczenie}

Lista stwierdzonych dotąd w Polsce przedstawicieli rodzaju Fusicladium [= Pollaccia, Spilocaea] obejmuje 12 gatunków, z których 3 należą obecnie do Passalora i Fusicladiella. Dane dotyczące 7 gatunków Fusicladium pochodzą wyłącznie ze źródeł publikowanych. Wy kaz uzupełniono o 3 gatunki nowe dla kraju: Fusicladium convolvularum, F. scribnerianum i $F$. virgaureae oraz nowe stanowiska 2 taksonów notowanych uprzednio. Dla wszystkich gatunków sporządzono mapy rozmieszczenia w Polsce, a dla gatunków nowo stwierdzonych również opisy i rysunki struktur morfologicznych. 
